\title{
Developing Preschool Activities to Support Children's Cognitive Skills and Examining Their Effectiveness
}

\author{
Gülçin Güven
}

Department of Primary Education, Atatürk Education Faculty, Marmara University, Turkey

Copyright $\mathrm{C} 2019$ by authors, all rights reserved. Authors agree that this article remains permanently open access under the terms of the Creative Commons Attribution License 4.0 International License

\begin{abstract}
The research, aims to inquire the effectiveness of "Cognitive Development Support Program" applied to 60-72 months old children attending pre-school education institutions, is in experimental design. One of the experimental designs, the pretest-posttest control-group design is used. All 152 students of an independent kindergarten aged 60-72 months in the 2016-2017 academic year at Ataşehir, Istanbul was selected as research population. Four of the children who were found not to have development in expected limits according to applied Denver II Development Screening Test were excluded from the evaluation process. Then, two classes (38 children) were randomly selected as experimental group and two classes (36 children) as control group among eight classes (148 children). Within the scope of the study six data collection tools were used, namely "Personal Information Form," "Denver II Developmental Screening Test," "Peabody Picture Vocabulary Test," "Early Geometry Skill Test," "Early Numeracy Test - ENT" and "Marmara Primary Education Readiness Scale." It has been observed in the research that Cognitive Support Program has a positive effect on the language skills, geometry skills and math skills of preschool children but it is similar to that of preschool education program in terms of readiness to primary school.
\end{abstract}

Keywords Cognitive Development Support Program, Language Skills, Geometry Skills and Math Skills, School Readiness

\section{Introduction}

A regular growth and change of a human individual's body structure and her social, emotional and cognitive characteristics as to have the ability to perform desired task is called as development. The term may also be defined as the process of a multi-dimensional change of a human individual through her life starting from the moment of fertilization, in terms of corporal, cognitive, emotional, social and sexual aspects (Driscoll \& Nagel 2002; Peker 2001; Unver 2003). Combination of heredity and environmental factors determine the process of development. The flourishing and development of the potentials acquired by inheritance is possible by providing appropriate environmental facilities (Senemoğlu, 2005). Development studies is divided into three general areas as physical, emotional-social and cognitive, to arrange the comprehensive and multidisciplinary works on the continuity and change of human individual in a more organized and useful manner (Berk, 2013).

The area of cognitive development is defined as all the changes that occur in the mental process such as perception, recall, reasoning, decision-making and problem solving (Gander \& Gardiner, 2015). The word cognition refers to mental activities that include learning and understanding of our world, and covers perception (the interpretation, organizing and reinterpretation of information acquired from the inner and outer world), memory (the acquisition and storage of perceived information), reasoning (the usage of the information to produce meaning and to reach conclusions), thinking (qualitative evaluation of information and its solutions) and comprehension (recognition of new relations between two or more parts of information) processes (Yavuzer, 2016a).

According to Piaget, whose works on cognitive development still maintains their validity, the child, who has an active role in obtaining information, is not the passive recipient of the world. Piaget tried to explain the cognitive processes that enable the children to perceive and interpret the world by examining the differences between children of different ages and the reasons of these differences. Cognitive processes is a broad term that includes concepts such as attention, perception, memory, language development, literacy, problem solving, recall, thinking, reason, creativity. Cognitive development is the process of holistic development of all the mental activities such as perception, imagination, memory and reasoning which enables the individual to understand and learn the 
world around her (Gander \& Gardiner, 2015; Küçükkaragöz, 2004; Senemoğlu, 2005). In summary, all these cognitive activities involve all behavioral processes and movements related to thinking and knowing, and cognitive development explains how these behavioral processes develop, how they understand the world and their mental development (Brewer, 1995; Oakley, 2004). Besides, cognitive development is parallel to other developmental areas (Katz, 1999). In order to support the cognitive development of children, motor, receptor-expressive language, social-emotional development and daily life skills need to be supported with educational programs applied in pre-school period (Arthur, 2001)

In early childhood, which forms the basis for her life, the child gains basic habits, develops her abilities, socializes by interacting with other people and develops her mental skills in a rich stimulating environment. Educational opportunities and support of adults during this period provide the child with the best way to prepare for life (Oktay, 2007). Basic concepts helps the realization of cognitive functions that are important for school achievements, such as identifying the objects in the environment, making comparisons, understanding the order of the events, understanding the positions and characteristics of people, places and objects (Boehm, 2001; Vygotsky, 1994). The acquisition of basic concepts in pre-school period is important for the success at school. Research shows that many basic concepts are learned during the pre-school years (Clark, 1983; French \& Nelson, 1985).

Apart from the family, early childhood education is one of the most influential factors that affect the cognitive development of the child. Setting the proper environmental conditions necessary to support children's specific perception and decision-making process is possible through early childhood education (Avc1, 2003). The success of this education depends on the quality of the conditions such as teacher, program, physical conditions, educational material, family, encountering rich stimulation in early period, providing a good education and educational environment (Koçak, 2001; Yavuzer, 2016; Yıldız \& Perihanoğlu, 2004).

All the opportunities the child has benefited in the preschool period are as important as the hereditary characteristics (Güneysu, 2001). Pre-school education is the crux of the whole education system that is not to be left to chance and should be guided by a serious, scientific and systematic arrangement since it undertakes a very important task of managing, encouraging and developing related features of the child who is motivated to learn and think (Senemoğlu, 2005; Sevinç, 2005). Therefore, pre-school education should be carried out in a scientific and systematic way (Küçükturan, 2003).

The best way for development of children is learning, that is, development and learning are parallel processes.
One can benefit from the development through learning by enabling the children to wonder and allowing them to make inquiries. To contribute to the cognitive development of children one should provide them to use their skills of asking, answering, researching and problem solving actively. The development of learning skills is the building blocks of knowledge. The children gain the ability to organize and classify information if they are exposed to stimulations necessary for the development in learning skills and concepts in early ages. In pre-school period, supporting the development of effective learning skills in children and the implementation of the programs for this purpose enable them to get different structural experiences (Charlesworth \& Radeloff, 1991; Jackman, 2005).

The preschool education provides the child to acquire successive life experiences cumulatively and to be able to relate them each other. In this context, the help of an adult for the child to be able to relate the subjects learned is very important (Oktay, 2004). When the literature is examined, it is seen how effective the environment is in the cognitive development of pre-school children. In this context, "Cognitive Development Support Program" was prepared by using Piaget's cognitive development theory. To realize a real understanding, real materials and activities such as experiment, excursion and observation are included in "Cognitive Development Support Program". It aimed to contribute to the development of all of the cognitive processes of the pre-school children such as perception, memory, thinking, logic, learning, description, concept gaining, problem solving and reasoning. Education programs are among the most important elements that facilitate cognitive development in pre-school period. A rich stimulating environment helps the child to improve the process of cognitive development. Considering the importance of stimuli and opportunities offered to children in early childhood, it is necessary to support the education programs implemented in educational institutions and to regulate them accordingly. In this context, in the research it aimed to test the effect of "Cognitive Development Support Program" on development of cognitive skills of children.

\section{Materials and Methods}

\subsection{Research Model}

The research, aims to inquire the effectiveness of "Cognitive Development Support Program" applied to 60-72 months old children attending pre-school education institutions, is in experimental design. One of the experimental designs, the pretest-posttest control-group design is used. In this design, participants are assigned as neutral to two or more intervention conditions and pretest is applied to them, then the intervention conditions are applied and finally the posttest is performed. This pattern was preferred for having a high internal validity because 
of assigning neutrally to treatment (Christensen, Johnson $\&$ Turner, 2015).

\subsection{Research Population}

All 152 students of an independent kindergarten aged 60-72 months in the 2016-2017 academic year at Ataşehir, Istanbul was selected as research population. Four of the children who were found not to have development in expected limits according to applied Denver II Development Screening Test were excluded from the evaluation process. Then, two classes (38 children) were randomly selected as experimental group and two classes (36 children) as control group among eight classes (148 children). 17 of the children in the experimental group are boys and 21 are girls while 19 of the children in the control group are boys and 17 are girls.

\subsection{Data Collection Tools}

Within the scope of the study six data collection tools were used, namely "Personal Information Form," "Denver II Developmental Screening Test," "Peabody Picture Vocabulary Test," "Early Geometry Skill Test," "Early Numeracy Test - ENT" and "Marmara Primary Education Readiness Scale."

\subsubsection{Personal Information Form}

The Personal Information Form developed by the researcher aims to obtain demographic information about gender, birth date, socioeconomic level and parental educational status of the students in the study group.

\subsubsection{Denver II Developmental Screening Test}

Denver II is an assessment tool designed to assess children's cognitive, social-emotional, lingual and motor development and to identify and monitor developmentally vulnerable children. Turkish adaptation and standardization work was carried out by Yalaz, Anlar and Bayoğlu (2010). The reliability of the test was .90 and the test-retest reliability was .86. It is composed of sub-fields of Personal-Social, Fine Motor, Language and Rough Motor. The test includes a total of 116 items. Assessment ensures the child's level of development to compare with his/ her normal peers (Yalaz, Anlar \& Bayoğlu, 2010).

\subsubsection{Peabody Picture Vocabulary Test}

The test was developed by Dunn and Dunn, and adapted into Turkish by Katz, Önen, Demir, Uzlukaya and Uludağ (1974). Reliability study is performed with 4012 children between the ages of 2.6 and 18.0. The reliability coefficients calculated from the obtained raw scores are between .64 and .84 . The test is applied individually. Within the scope of the test, there are questions aiming to determine the vocabulary development using pictures. There are 100 cards and registration forms, each consisting of four pictures. The child is asked to point the proper picture to the word told to him / her from four pictures. The score that the child received is converted to the receptive language age previously determined according to the place where he /she lives (Katz et al., 1974).

\subsubsection{Early Geometry Skills Test}

The test developed by Sezer and Güven aims to determine the geometry skill levels of the children aged 5-7 years. The scale determined by Burger and Shaughnessy (1986) is based on the characteristics of the first two of the geometric thinking levels of van Hiele, namely the visual level and the level of analysis. In the Early Geometry Skills Test, the skills such as, shape namings, shape drawings, building imagery, building with blocks, creating new shapes by combining shapes, creating shapes using rods, visualization of the shapes, rotating, scrolling, sliding with atypical and invalid samples of the shapes, ratios, openness and closeness features, space and spatial relations, and patterns, are evaluated under a total of 42 items.

\subsubsection{Early Numeracy Test}

The test is developed by Van Luit et al. (1994), and adapted to Turkish by Önkol (2012). In the reliability study of the Early Numeracy Test A Form, the test-retest correlation is .84 , Cronbach's alpha internal consistency coefficient is .94 , and the KR-20 reliability is .91 . ENT is developed to determine the early mathematical competence of children. The Netherlands Utrecht University Early Numeracy Test (ENT) is a scale used for measuring the level of concept development in early numbers of preschool and primary school first grade pupils. The test has two parallel forms (Form A and B) each consisting of 45 questions. There are 5 questions in each one of the 9 sub-dimensions of the test. The sub-dimensions of the Early Numeracy Test are as follows; concepts of comparison, classification, one-to-one correspondence, seriation, the use of number words, structured counting, resultative counting, general understanding of numbers, and estimation.

\subsubsection{Marmara Primary Education Readiness Scale}

The scale was developed and standardized by Polat-Unutkan (2003) in order to determine the level of readiness of children aged between 60-78 months. The Marmara Primary Education Readiness Scale consists of two parts, namely the Development Form and the Application Form. The Development Form consists of 153 items and four subscales, including mental-language development (74 items), social-emotional development (40 items), physical development (23 items) and self-care skills (16 items). The frequency of the child's showing a certain behavior was evaluated by preschool teachers using four-point likert type scale as "always, often, sometimes, never". The form consists of five subscales as mathematical skills (47 items), science skills (14 items), 
sound studies ( 8 items), line studies ( 3 items), labyrinths ( 2 items) in a total of 74 items. The researcher made the children fill in the form one by one. Each application lasts between 30-40 minutes. Evaluation is made by giving one point for each right answer and zero point for each wrong answer. The application form of "Marmara Primary School Readiness Scale" was used in this study.

\subsection{Processing}

The population of the study is 152 students from an independent kindergarten in Ataşehir aged 60-72 months whose families are in middle socioeconomic level in the 2016-2017 academic year. The Denver Developmental Screening Test was used to determine if the experimental groups treated with the Cognitive Development Support Program and the control groups share the similar developmental level. After the developmental evaluation, one class of students with a low average grade was excluded from among the eight preschool education classes. Then, two experiment groups and two control groups were selected among the students from remaining seven classes whose developmental levels are similar.

Preliminary tests were applied to the students in the experimental and control groups for a period of ten days. The implementation protocol of the Cognitive Development Support Program was followed the four hours of training of the preschool class teachers by the researcher. The "Cognitive Development Support Program" was applied to the students in the experimental group by the class teachers for 14 weeks. While this period, the researcher carried out monthly evaluation meetings with the teachers in the experimental group and monitored the implementation process.

Following the Cognitive Development Support Program applied to the experimental group, posttests were applied to the experimental and control groups within two weeks.

\subsubsection{Cognitive Development Support Program}

The Cognitive Development Support Program designed for children in the pre-school period (60-72 months) aims to contribute to the development of all cognitive processes such as perception, memory, thinking, logic, learning, description, concept gaining, problem solving and reasoning. It is an educational program that aims to support and develop children's verbal language skills, common knowledge, writing awareness activities, phonology, sound awareness, perception, recall, basic concepts and math skills.

The philosophical and theoretical foundations of the program have been formed by examining the domestic as well as the global literature. As a result of the literature examinations, the program is decided to implement a constructivist approach. The constructivist approach based on Piaget's studies on cognitive development and knowledge formation is derived from philosophy and psychology. It explains the nature of the learning-teaching process and is not a teaching method or strategy. The constructivist approach focuses on learning rather than teaching, and assumes that the knowledge is structured by the learner. It is the process of understanding and interpreting the newly encountered knowledge with the guidance of the teacher by taking advantage of past learning. Construction of new knowledge is more important than the teacher made child absorb it, and learners can absorb it and use it in different contexts more effectively when they discover an event or concept on their own (Erdem \& Demirel, 2002; Özbek, 2005; Brooks \&Brooks, 2001; Deveci, 2003). In the Cognitive Development Support Program prepared by these information, the child is at the center and the teacher's role is to guide him/ her.

In this study, it is aimed to prepare a comprehensive activity program covering different types of activities. Cognitive Development Support Program is prepared by the researcher regarding the Preschool Education Program put into action in 2013 by the Ministry of Education and integrated to its requirements is a 14-week program consisting of a total of 70 activity plans. The achievements and indicators in the program are selected from the 2013 Preschool Education Program. The activities in the program are prepared according to selected achievements and indicators. While preparing the activities it is accepted that cognitive development is in parallel with other developmental areas (Katz, 1999) and to support different development areas, different kinds of activities (Turkish, art, drama, music, movement, play, science, math, field trips) and working ways (individual activity, small group activity, large group activity) are included as far as possible.

The aim of the course is to improve the cognitive development of children by using different kinds of activities prepared in the Cognitive Support Program, namely verbal-language skills, general knowledge, writing awareness / pre-writing activities, alphabet knowledge, sound awareness, perception, recall, concept development and mathematical skills. The distribution of the types of activities included in the daily training flow of the Cognitive Support Program developed for this purpose is presented in the table below. 
Table 1. Cognitive Support Program Activity Types and Skills Distribution

\begin{tabular}{|c|c|c|c|c|c|c|c|c|c|}
\hline \multirow{2}{*}{ Targeted Skills } & \multicolumn{9}{|c|}{ Activity Types } \\
\hline & Turkish & Art & Drama & Music & Motion & Play & Science & Math & Field trips \\
\hline Verbal-language skills & 2 & - & - & - & - & - & 2 & - & - \\
\hline General knowledge & 2 & - & - & - & - & - & 2 & - & - \\
\hline Writing awareness/ pre-writing activities & - & 2 & 1 & - & - & 1 & 2 & - & - \\
\hline Alphabet knowledge & 2 & 2 & 2 & - & - & 2 & 2 & - & - \\
\hline Sound awareness & 2 & 2 & 2 & 1 & 2 & 2 & 2 & - & - \\
\hline Perception & 2 & 2 & 1 & 1 & - & 2 & 1 & - & 1 \\
\hline Recall & - & 2 & 1 & - & 1 & 2 & 2 & - & - \\
\hline Concept development & 2 & - & - & - & 1 & 1 & 2 & - & - \\
\hline Mathematics & - & 1 & - & - & 1 & 2 & 2 & 3 & - \\
\hline
\end{tabular}

The mathematical activities of the Preschool Education Program enacted by the Ministry of Education in 2013 in Turkey must enable children to notice patterns in their environment, to develop assumptions and to try them, to solve problems, to reason out and to communicate using mathematical concepts. The aim of preparatory reading and writing activities is to provide children with the preliminary skills necessary to fasten their learning how to read and write in primary school. Including different types of play (unstructured play / free play, semi-structured play activities, structured play activities) in a balanced manner, the Program aims to support children development in all aspects to the most advanced level. Music activities aim to support children's cognitive, language, motor, social and emotional development. Science activities that move children to curiosity, asking questions, observing, researching, inquiring and exploring aim to support cognitive development. Field trips aim to meet the first hand and significant learning needs of children through research, problem solving and event observation.

\subsection{Data Analysis}

The data obtained from the study were recorded and analyzed using statistical analysis software. Denver Developmental Screening Test was used to determine whether the developmental level of the experimental and the control groups are similar. After the evaluation on their developmental levels, a low average grade class among the eight preschool classes was removed from the groups and two of the remaining seven classes were randomly assigned as experimental and two as control groups. Data collection tool pretests were applied to the selected experimental and control groups. According to Kolmogorov-Smirnov test results and skewness-kurtosis values, the data were found to follow a normal distribution. Independent Samples t-Test was performed on pretest scores to determine whether there is a significant difference between the initial levels of the experimental groups (Pallant, 2001). After the application of Cognitive
Support Program to the experimental group, posttest was performed and it was found that these data also follow a normal distribution. In order to determine the difference between the posttest scores of the experimental and the control groups, Independent Samples $t$ Test was performed on them. In the last stage, Paired Sample t-Test was performed to determine whether there is a significant difference between the pretest-posttest scores of the experimental and the control groups.

\section{Findings}

In this section, the findings on the research problem and firstly, the results of the t-test which was performed to determine whether there is a significant difference between the pretest scores of the experimental and control groups are presented. According to the t-test results, the total mean scores of Peabody Picture Vocabulary Test and Early Geometry Skills Test which are applied as pretest and the mean scores of Early Numeracy Test and Marmara Primary Education Readiness Scale - Application Form for all subscales, no significant difference between the groups is detected $(p>05)$. These results also indicate that experimental and control groups included in the study are equivalent.

T-test results of the dependent sample are examined to determine whether there is a significant difference between the pretest-posttest means scores of the children in the experimental group. The t-test results of the Peabody Picture Vocabulary Test and Early Geometry Skills Test pretest-posttest mean scores of the children in the experimental group are presented in Table 2.

When Table 2 is examined, it is found that there is a significant difference between the pretest and posttest mean scores of the children in the experimental group in Peabody Picture Vocabulary Test $(\mathrm{t}=-10,274)$ and Early Geometry Skills Test $(t=-7,909)$. Examining the mean scores shows that, posttest mean scores of Peabody Picture Vocabulary Test and Early Geometry Skills Test are higher than the pretest mean scores. 
Table 3 shows the dependent sample t-test results for the difference between the pretest-posttest mean scores of the children in the experimental group in Early Numeracy Test.2.5.1. Tables Title. Table 2 shows that there is a significant difference between the pretest-posttest mean scores of the children in the experimental group in Early Numeracy Test in the subscales of Concepts Comparison $(\mathrm{t}=-2,217)$, Classification $(\mathrm{t}=-3,224)$, One to One Correspondence $(\mathrm{t}=-2,890)$, Seriation $(\mathrm{t}=-3,389)$, Counting $(t=-3,883)$, Structured Counting $(t=-2,920)$, General Knowledge of Numbers $(t=-3,635)$ and Calculation $(t=-5,119)(p<.05)$. Examining the mean scores shows that the posttest mean scores of Early Numeracy Test are higher than the pretest mean scores in all subscales.

Table 4 presents the dependent sample t-test results of the difference between the pretest-posttest mean scores of the children in the experimental group in Marmara Primary School Readiness Scale - Application Form.

Table 4 shows that there is a significant difference between pretest-posttest mean scores of the children in the experimental group in Marmara Primary School Readiness Scale - Application Form in the subscales of Mathematics skills $(\mathrm{t}=-10,333)$, Science skills $(\mathrm{t}=$ $-3,949)$, Sound studies $(t=-2,162)$ and Drawing studies $(t$ $=-2,634)$ subscale scores $(\mathrm{p}<.05)$. When the mean scores are examined, it is found that the posttest mean scores in these subscales of the scale are higher than the pretest mean scores. However, there are not significant differences between the pretest-posttest mean scores in Labyrinths $(t=-1,781)$ subscale of Marmara Primary School Readiness Scale - Application Form ( $p>$.05).

Table 2. The t-test results of the difference between pretest-posttest mean scores of the children in the experimental group in Peabody Picture Vocabulary Test and Early Geometry Skills Test

\begin{tabular}{|c|c|c|c|c|c|c|c|}
\hline Scale & Test & $\mathbf{n}$ & $\bar{X}$ & Ss & $\mathbf{t}$ & Sd & $p$ \\
\hline \multirow{2}{*}{ Peabody Picture Vocabulary Test } & Pretest & 38 & 7.68 & 2.52 & -10.274 & 37 &, $000^{*}$ \\
\hline & Posttest & 38 & 9.97 & 2.77 & & & \\
\hline \multirow{2}{*}{ Early Geometry Skills Test } & Pretest & 38 & 34.55 & 8.76 & -7.909 & 37 &, $000^{*}$ \\
\hline & Posttest & 38 & 40.23 & 5.62 & & & \\
\hline
\end{tabular}

Table 3. T-test results for the difference between the pretest-posttest mean scores of the children in the experimental group in Early Numeracy Test

\begin{tabular}{|c|c|c|c|c|c|c|c|}
\hline Early Numeracy Test & Test & $\mathbf{n}$ & $\bar{X}$ & Ss & $\mathbf{t}$ & Sd & $p$ \\
\hline \multirow{2}{*}{ Concepts Comparison } & Pretest & 38 & 4.57 &, 68 & -2.217 & 37 &, $033^{*}$ \\
\hline & Posttest & 38 & 4.76 & ,48 & & & \\
\hline \multirow{2}{*}{ Classification } & Pretest & 38 & 3.89 &, 89 & -3.224 & 37 &, $003 *$ \\
\hline & Posttest & 38 & 4.15 &, 71 & & & \\
\hline \multirow{2}{*}{ One to One Correspondence } & Pretest & 38 & 4.18 &, 60 & -2.890 & 37 &, $006^{*}$ \\
\hline & Posttest & 38 & 4.36 &, 54 & & & \\
\hline \multirow{2}{*}{ Seriation } & Pretest & 38 & 3.31 &, 66 & -3.389 & 37 &, $002 *$ \\
\hline & Posttest & 38 & 3.63 &, 71 & & & \\
\hline \multirow{2}{*}{ Counting } & Pretest & 38 & 2.94 & ,46 & -3.883 & 37 &, $000^{*}$ \\
\hline & Posttest & 38 & 3.23 &, 48 & & & \\
\hline \multirow{2}{*}{ Structured Counting } & Pretest & 38 & 3.18 &, 76 & -4.482 & 37 &, $000^{*}$ \\
\hline & Posttest & 38 & 3.68 &, 77 & & & \\
\hline \multirow{2}{*}{ Resultative Counting } & Pretest & 38 & 3.31 &, 57 & -2.920 & 37 &, $006^{*}$ \\
\hline & Posttest & 38 & 3.60 &, 67 & & & \\
\hline \multirow{2}{*}{ General Knowledge of Numbers } & Pretest & 38 & 2.13 &, 77 & -3.635 & 37 &, $001 *$ \\
\hline & Posttest & 38 & 2.65 & ,93 & & & \\
\hline \multirow{2}{*}{ Calculation } & Pretest & 38 & 2.63 & 1.07 & -5.119 & 37 &, $000^{*}$ \\
\hline & Posttest & 38 & 3.44 & ,95 & & & \\
\hline
\end{tabular}


Table 4. T-test results of the difference between the pretest-posttest mean scores of the children in the experimental group in Marmara Primary School Readiness Scale - Application Form.

\begin{tabular}{|c|c|c|c|c|c|c|c|}
\hline Early Numeracy Test & Test & n & $\bar{X}$ & Ss & $\mathbf{t}$ & Sd & $p$ \\
\hline \multirow{2}{*}{ Concepts Comparison } & Pretest & 38 & 4.57 & ,68 & \multirow[t]{2}{*}{-2.217} & \multirow[t]{2}{*}{37} & \multirow[t]{2}{*}{, $033 *$} \\
\hline & Posttest & 38 & 4.76 &, 48 & & & \\
\hline \multirow{2}{*}{ Classification } & Pretest & 38 & 3.89 &, 89 & \multirow[t]{2}{*}{-3.224} & \multirow[t]{2}{*}{37} & \multirow[t]{2}{*}{, $003^{*}$} \\
\hline & Posttest & 38 & 4.15 &, 71 & & & \\
\hline \multirow{2}{*}{ One to One Correspondence } & Pretest & 38 & 4.18 & ,60 & \multirow[t]{2}{*}{-2.890} & \multirow[t]{2}{*}{37} & \multirow[t]{2}{*}{, $006^{*}$} \\
\hline & Posttest & 38 & 4.36 &, 54 & & & \\
\hline \multirow{2}{*}{ Seriation } & Pretest & 38 & 3.31 & ,66 & \multirow[t]{2}{*}{-3.389} & \multirow[t]{2}{*}{37} & \multirow[t]{2}{*}{, $002 *$} \\
\hline & Posttest & 38 & 3.63 &, 71 & & & \\
\hline \multirow{2}{*}{ Counting } & Pretest & 38 & 2.94 &, 46 & \multirow[t]{2}{*}{-3.883} & \multirow[t]{2}{*}{37} & \multirow[t]{2}{*}{, $000^{*}$} \\
\hline & Posttest & 38 & 3.23 &, 48 & & & \\
\hline \multirow{2}{*}{ Structured Counting } & Pretest & 38 & 3.18 &, 76 & \multirow[t]{2}{*}{-4.482} & \multirow[t]{2}{*}{37} & \multirow[t]{2}{*}{, $000^{*}$} \\
\hline & Posttest & 38 & 3.68 &, 77 & & & \\
\hline \multirow{2}{*}{ Resultative Counting } & Pretest & 38 & 3.31 &, 57 & \multirow[t]{2}{*}{-2.920} & \multirow[t]{2}{*}{37} & \multirow[t]{2}{*}{, $006^{*}$} \\
\hline & Posttest & 38 & 3.60 & 67 & & & \\
\hline \multirow{2}{*}{ General Knowledge of Numbers } & Pretest & 38 & 2.13 &, 77 & \multirow[t]{2}{*}{-3.635} & \multirow[t]{2}{*}{37} & \multirow[t]{2}{*}{, $001 *$} \\
\hline & Posttest & 38 & 2.65 & ,93 & & & \\
\hline \multirow{2}{*}{ Calculation } & Pretest & 38 & 2.63 & 1.07 & \multirow[t]{2}{*}{-5.119} & \multirow[t]{2}{*}{37} & \multirow[t]{2}{*}{, $000 *$} \\
\hline & Posttest & 38 & 3.44 & ,95 & & & \\
\hline
\end{tabular}

Table 5. The results of the t-test for the pretest-posttest mean scores of the children in the control group in Peabody Picture Vocabulary Test and Early Geometry Skills Test.

\begin{tabular}{|c|c|c|c|c|c|c|c|}
\hline Scale & Test & $\mathbf{n}$ & $\bar{X}$ & Ss & $\mathbf{t}$ & Sd & $p$ \\
\hline \multirow{2}{*}{ Peabody Picture Vocabulary Test } & Pretest & 36 & 6.88 & 2.23 & \multirow[t]{2}{*}{-8.753} & \multirow[t]{2}{*}{35} & \multirow[t]{2}{*}{, $000^{*}$} \\
\hline & Posttest & 36 & 8.38 & 2.11 & & & \\
\hline \multirow{2}{*}{ Early Geometry Skills Test } & Pretest & 36 & 34.22 & 8.77 & \multirow[t]{2}{*}{-6.798} & \multirow[t]{2}{*}{35} & \multirow[t]{2}{*}{, $000^{*}$} \\
\hline & Posttest & 36 & 35.66 & 8.41 & & & \\
\hline
\end{tabular}

In this section, it is presented that the results of the dependent sample t-test applied to determine whether there is a significant difference between the pretest and posttest mean scores of the children in the control group. OobiThe results of the t-test for the pretest-posttest mean scores of the children in the control group in Peabody Picture Vocabulary Test and Early Geometry Skills Test are presented in Table 5.

When Table 5 is examined, it is found that there is a significant difference between pretest-posttest mean scores of Peabody Picture Vocabulary Test $(\mathrm{t}=-8,753)$ and Early Geometry Skills Test $(\mathrm{t}=-6,798)$ of the children in the control group in the control group $(\mathrm{p}<.05)$. When the mean scores are examined, it is seen that the posttest mean scores of Peabody Picture Vocabulary Test and Early Geometry Skills Test are higher than pretest mean scores of the children in the control group.

Table 6 presents the dependent sample t-test results for the difference between the pretest and posttest mean scores of the children in the control group in the Early Numeracy Test.

Table 6 shows that there is a significant difference between the pretest-posttest mean scores of the children in the control group in Early Numeracy Test subscales of One to One Correspondence $(\mathrm{t}=2,092)$, Counting $(\mathrm{t}=$ 2,743), General Knowledge of Numbers $(t=-2,712)$ and Calculation $(\mathrm{t}=-2,256)(\mathrm{p}<.05)$. When the mean scores are examined, it is found that the posttest mean scores of the Early Numeracy Test is higher than pretest mean scores in the subscales of One to One Correspondence and Counting and that the posttest mean scores in the subscales of General Knowledge of Numbers and Calculation. In addition, there is no significant difference between the pretest-posttest mean scores of the children in the control group in Concepts Comparison $(\mathrm{t}=1,869)$, Classification $(t=1,745)$, Seriation $(t=, 902)$, Structured Counting $(\mathrm{t}=1,313)$ and Resultative Counting $(\mathrm{t}=, 627)$ subscales of Early Numeracy Test ( $\mathrm{p}>.05)$. 
Table 6. The t-test results in Early Numeracy Test for the difference between the pretest and posttest mean scores of the children in the control group.

\begin{tabular}{|c|c|c|c|c|c|c|c|}
\hline Early Numeracy Test & Test & $\mathbf{n}$ & $\bar{X}$ & Ss & $\mathbf{t}$ & Sd & $p$ \\
\hline \multirow{2}{*}{ Concepts Comparison } & Pretest & 36 & 4.38 & ,68 & \multirow[t]{2}{*}{1.869} & \multirow[t]{2}{*}{35} & \multirow[t]{2}{*}{, 070} \\
\hline & Posttest & 36 & 4.19 & ,66 & & & \\
\hline \multirow{2}{*}{ Classification } & Pretest & 36 & 4.13 & ,63 & \multirow[t]{2}{*}{1.745} & \multirow[t]{2}{*}{35} & \multirow[t]{2}{*}{, 090} \\
\hline & Posttest & 36 & 3.94 &, 71 & & & \\
\hline \multirow{2}{*}{ One to One Correspondence } & Pretest & 36 & 3.91 &, 55 & \multirow[t]{2}{*}{2.092} & \multirow[t]{2}{*}{35} & \multirow[t]{2}{*}{, $044 *$} \\
\hline & Posttest & 36 & 3.69 &, 70 & & & \\
\hline \multirow{2}{*}{ Seriation } & Pretest & 36 & 3.44 & ,69 & \multirow[t]{2}{*}{,902 } & \multirow[t]{2}{*}{35} & \multirow[t]{2}{*}{, 373} \\
\hline & Posttest & 36 & 3.36 & ,63 & & & \\
\hline \multirow{2}{*}{ Counting } & Pretest & 36 & 3.00 &, 47 & \multirow[t]{2}{*}{2.743} & \multirow[t]{2}{*}{35} & \multirow[t]{2}{*}{, $010^{*}$} \\
\hline & Posttest & 36 & 2.69 &, 70 & & & \\
\hline \multirow{2}{*}{ Structured Counting } & Pretest & 36 & 2.97 &, 55 & \multirow[t]{2}{*}{1.313} & \multirow[t]{2}{*}{35} & \multirow[t]{2}{*}{,198 } \\
\hline & Posttest & 36 & 2.77 &, 83 & & & \\
\hline \multirow{2}{*}{ Resultative Counting } & Pretest & 36 & 3.22 &, 42 & \multirow[t]{2}{*}{, 627} & \multirow[t]{2}{*}{35} & \multirow[t]{2}{*}{, 535} \\
\hline & Posttest & 36 & 3.16 &, 56 & & & \\
\hline \multirow{2}{*}{ General Knowledge of Numbers } & Pretest & 36 & 2.30 &, 46 & \multirow[t]{2}{*}{-2.712} & \multirow[t]{2}{*}{35} & \multirow[t]{2}{*}{, $010^{*}$} \\
\hline & Posttest & 36 & 2.58 & ,64 & & & \\
\hline \multirow{2}{*}{ Calculation } & Pretest & 36 & 2.33 & 1.17 & \multirow[t]{2}{*}{-2.256} & \multirow[t]{2}{*}{35} & \multirow[t]{2}{*}{, $030^{*}$} \\
\hline & Posttest & 36 & 2.55 & 1.08 & & & \\
\hline
\end{tabular}

Table 7. T-test results of the pretest and posttest mean scores of the children in control group in Marmara Primary School Readiness Scale Application Form

\begin{tabular}{|c|c|c|c|c|c|c|c|}
\hline $\begin{array}{c}\text { Marmara Primary School Readiness Scale - } \\
\text { Application Form }\end{array}$ & Test & $\mathbf{n}$ & $\bar{X}$ & Ss & $\mathbf{t}$ & Sd & $p$ \\
\hline \multirow{2}{*}{ Mathematics skills } & Pretest & 36 & 28.08 & 8.96 & \multirow[t]{2}{*}{-7.123} & \multirow[t]{2}{*}{35} & \multirow[t]{2}{*}{, $000 *$} \\
\hline & Posttest & 36 & 30.02 & 8.32 & & & \\
\hline \multirow{2}{*}{ Science skills } & Pretest & 36 & 7.05 & 1.88 & \multirow[t]{2}{*}{-3.873} & \multirow[t]{2}{*}{35} & \multirow[t]{2}{*}{, $000 *$} \\
\hline & Posttest & 36 & 7.55 & 1.55 & & & \\
\hline \multirow{2}{*}{ Sound studies } & Pretest & 36 & 47 & 1.08 & \multirow[t]{2}{*}{-1.963} & \multirow[t]{2}{*}{35} & \multirow[t]{2}{*}{, 058} \\
\hline & Posttest & 36 & 61 & 1.10 & & & \\
\hline \multirow{2}{*}{ Drawing studies } & Pretest & 36 & 1.55 & 60 & \multirow[t]{2}{*}{-1.784} & \multirow[t]{2}{*}{35} & \multirow[t]{2}{*}{, 083} \\
\hline & Posttest & 36 & 1.63 &, 54 & & & \\
\hline \multirow{2}{*}{ Labyrinths } & Pretest & 36 &, 52 & ,60 & \multirow[t]{2}{*}{-1.784} & \multirow[t]{2}{*}{35} & \multirow[t]{2}{*}{,083 } \\
\hline & Posttest & 36 & ,61 & ,59 & & & \\
\hline
\end{tabular}

Table 7 presents the dependent sample t-test results of the pretest and posttest mean scores of the children in control group in Marmara Primary School Readiness Scale - Application Form. According to Table 7, there is a significant difference between the pretest-posttest mean scores of the children in the control group in Mathematics skills $(\mathrm{t}=-7,123)$ and Science skills $(\mathrm{t}=-3,873)$ subscales of the Marmara Primary School Readiness Scale Application Form $(p<.05)$. When the mean scores are examined, it is found that the posttest mean scores in these subscales of the scale are higher than the pretest mean scores. However, there is no significant difference between the pretest-posttest mean scores of the Marmara Primary School Readiness - Application Form Sound studies $(\mathrm{t}=-1,963)$, Drawing studies $(\mathrm{t}=-1,784)$ and Labyrinths $(\mathrm{t}=-1,784)$ subscales $(\mathrm{p}>.05)$.
Finally, the t-test results are performed to determine whether there is a significant difference between the posttest mean scores of the experimental and control groups. Firstly, the t-test results of the posttest mean scores of the children in the experimental and control group in Peabody Picture Vocabulary Test and Early Geometry Skills Test are presented in Table 8.

Table 8 shows that there is a significant difference between Peabody Picture Vocabulary Test and Early Geometry Skills Test total posttest mean scores in experimental $(\mathrm{t}=2,752)$ and control $(\mathrm{t}=2,760)$ groups $(\mathrm{p}<.05)$. When the posttest mean scores are examined, it is found that the mean scores of Peabody Picture Vocabulary Test and Early Geometry Skills Test in the experimental group are higher than the children in the control group. 
Table 8. The t-test results of the posttest mean scores of the children in the experimental and control group in Peabody Picture Vocabulary Test and Early Geometry Skills Test

\begin{tabular}{|c|c|c|c|c|c|c|c|}
\hline Scale & Group & $\mathbf{n}$ & $\bar{X}$ & Ss & $\mathbf{t}$ & Sd & $p$ \\
\hline \multirow{2}{*}{ Peabody Picture Vocabulary Test } & Experiment & 38 & 9.97 & 2.77 & 2.752 & 72 &, $007 *$ \\
\hline & Control & 36 & 8.38 & 2.11 & & & \\
\hline \multirow{2}{*}{ Early Geometry Skills Test } & Experiment & 38 & 40.23 & 5.62 & 2.760 & 72 &, $007 *$ \\
\hline & Control & 36 & 35.66 & 8.41 & & & \\
\hline
\end{tabular}

Table 9. The t-test results of Early Numeracy Test posttest mean scores of the children in the experimental and control groups

\begin{tabular}{|c|c|c|c|c|c|c|c|}
\hline Early Numeracy Test & Group & $\mathbf{n}$ & $\bar{X}$ & Ss & $\mathbf{t}$ & Sd & $p$ \\
\hline \multirow{2}{*}{ Concepts Comparison } & Experiment & 38 & 4.76 & ,48 & 4.191 & 72 &, $000^{*}$ \\
\hline & Control & 36 & 4.19 & ,66 & & & \\
\hline \multirow{2}{*}{ Classification } & Experiment & 38 & 4.15 &, 71 & 1.281 & 72 & ,204 \\
\hline & Control & 36 & 3.94 &, 71 & & & \\
\hline \multirow{2}{*}{ One to One Correspondence } & Experiment & 38 & 4.36 &, 54 & 4.607 & 72 &, $000^{*}$ \\
\hline & Control & 36 & 3.69 &, 70 & & & \\
\hline \multirow{2}{*}{ Seriation } & Experiment & 38 & 3.63 &, 71 & 1.714 & 72 &, 091 \\
\hline & Control & 36 & 3.36 &, 63 & & & \\
\hline \multirow{2}{*}{ Counting } & Experiment & 38 & 3.23 &, 48 & 3.844 & 72 &, $000^{*}$ \\
\hline & Control & 36 & 2.69 &, 70 & & & \\
\hline \multirow{2}{*}{ Structured Counting } & Experiment & 38 & 3.68 &, 77 & 4.853 & 72 &, $000^{*}$ \\
\hline & Control & 36 & 2.77 &, 83 & & & \\
\hline \multirow{2}{*}{ Resultative Counting } & Experiment & 38 & 3.60 &, 67 & 3.020 & 72 &, $003 *$ \\
\hline & Control & 36 & 3.16 &, 56 & & & \\
\hline \multirow{2}{*}{ General Knowledge of Numbers } & Experiment & 38 & 2.65 & ,93 &, 396 & 72 & ,694 \\
\hline & Control & 36 & 2.58 & ,64 & & & \\
\hline \multirow{2}{*}{ Calculation } & Experiment & 38 & 3.44 & ,95 & 3.775 & 72 &, $000^{*}$ \\
\hline & Control & 36 & 2.55 & 1.08 & & & \\
\hline
\end{tabular}

The t-test results of Early Numeracy Test posttest mean scores of the children in the experimental and control groups are presented in Table 9.

Table 9 shows that there is a significant difference between the mean scores of experimental and control groups in subscales of Concepts Comparison $(t=4,191)$, One to One Correspondence $(t=4,607)$, Counting $(t=$ $3,888)$, Structured Counting $(\mathrm{t}=4,853)$, Resultative Counting $(t=3,020)$ and Calculation $(t=3,775)$ of Early Numeracy Test applied as a posttest $(\mathrm{p}<.05)$. When the posttest mean scores are examined, it is found that the mean scores of the children in experimental group is higher than the control group in Concepts Comparison,
One to One Correspondence, Counting, Structured Counting, Resultative Counting and Calculation subscales of Early Numeracy Test. In addition, it is found that there is no significant difference between the experimental and control groups in the mean scores of Classification $(t=$ $1,281)$, Seriation $(t=1,714)$ and General Knowledge of Numbers $(t=396)$ subscales of Early Numeracy Test $(\mathrm{p}>.05)$.

Marmara Primary School Readiness Scale - Application Form posttest mean scores t-test results of the children in the experimental and control groups are presented in Table 10. 
Table 10. The t-test results of the children in the experimental and control groups in Marmara Primary School Readiness Scale - Application Form posttest mean scores

\begin{tabular}{|c|c|c|c|c|c|c|c|}
\hline $\begin{array}{c}\text { Marmara Primary School Readiness Scale - } \\
\text { Application Form }\end{array}$ & Group & $\mathbf{n}$ & $\bar{X}$ & Ss & $\mathbf{t}$ & Sd & $p$ \\
\hline \multirow{2}{*}{ Mathematics skills } & Experiment & 38 & 33.78 & 7.69 & \multirow[t]{2}{*}{2.020} & \multirow[t]{2}{*}{72} & \multirow[t]{2}{*}{, $047^{*}$} \\
\hline & Control & 36 & 30.02 & 8.32 & & & \\
\hline \multirow{2}{*}{ Science skills } & Experiment & 38 & 8.00 & 1.39 & \multirow[t]{2}{*}{1.295} & \multirow[t]{2}{*}{72} & \multirow[t]{2}{*}{,200 } \\
\hline & Control & 36 & 7.55 & 1.55 & & & \\
\hline \multirow{2}{*}{ Sound studies } & Experiment & 38 &, 71 & 1.27 & \multirow[t]{2}{*}{, 358} & \multirow[t]{2}{*}{72} & \multirow[t]{2}{*}{, 721} \\
\hline & Control & 36 & ,61 & 1.10 & & & \\
\hline \multirow{2}{*}{ Drawing studies } & Experiment & 38 & 1.63 &, 54 & \multirow[t]{2}{*}{-.058} & \multirow[t]{2}{*}{72} & \multirow[t]{2}{*}{,954 } \\
\hline & Control & 36 & 1.63 &, 54 & & & \\
\hline \multirow{2}{*}{ Labyrinths } & Experiment & 38 & ,63 & ,63 & \multirow[t]{2}{*}{, 143} & \multirow[t]{2}{*}{72} & \multirow[t]{2}{*}{, 887} \\
\hline & Control & 36 & ,61 &, 59 & & & \\
\hline
\end{tabular}

The t-test results of Early Numeracy Test posttest mean scores of the children in the experimental and control groups are presented in Table 9.

Table 9 shows that there is a significant difference between the mean scores of experimental and control groups in subscales of Concepts Comparison $(t=4,191)$, One to One Correspondence $(t=4,607)$, Counting $(t=$ $3,888)$, Structured Counting $(\mathrm{t}=4,853)$, Resultative Counting $(t=3,020)$ and Calculation $(t=3,775)$ of Early Numeracy Test applied as a posttest $(\mathrm{p}<.05)$. When the posttest mean scores are examined, it is found that the mean scores of the children in experimental group is higher than the control group in Concepts Comparison, One to One Correspondence, Counting, Structured Counting, Resultative Counting and Calculation subscales of Early Numeracy Test. In addition, it is found that there is no significant difference between the experimental and control groups in the mean scores of Classification $(t=$ $1,281)$, Seriation $(t=1,714)$ and General Knowledge of Numbers $(t=396)$ subscales of Early Numeracy Test (p> .05).

Marmara Primary School Readiness Scale - Application Form posttest mean scores t-test results of the children in the experimental and control groups are presented in Table 10.

Table 10 shows that there is a significant difference between experimental and control groups in Mathematics skills subscale mean scores of Marmara Primary School Readiness Scale - Application Form applied as posttest $(\mathrm{t}=2,020 ; \mathrm{p}<.05)$. When the posttest mean scores are examined, it is found that the mean scores of Mathematics skills subscale mean scores of the children in the experimental group are higher than the control group. In addition to this, the difference between the experimental and control groups is not significant in the Science skills $(t=1,295)$, Sound studies $(t=358)$, Drawing studies $(t=$ $-, 058)$ and Labyrinths $(t=, 143)$ subscale posttest mean scores $(\mathrm{p}>.05)$.

\section{Conclusions}

The effectiveness of the Cognitive Support Program which is prepared for the development of all cognitive processes such as perception, memory, thinking, logic, learning, description, concept gaining, problem solving and reasoning in preschool children (60-72 months) is tested with this study. As a result of the analyses, the Cognitive Support Program is found to have an effect on children's mathematics, geometry, receptive language skills and readiness to primary school. According to the results of the study, it is found that Peabody Picture Vocabulary Test posttest mean scores of the children in the experimental group and the control group were higher than the pre-test mean scores. According to this result, Cognitive Support Program increases the receptive language skills of the children in the pre-school education program implemented by the Ministry of Education. However, when the posttest means scores of the experimental and the control groups were examined, it is found that Peabody Picture Vocabulary Test mean scores of the children in the experimental group were higher than the mean scores of the control group children. It has been determined that the Cognitive Support Program has a positive effect on the development of receptive language skills of the children. In the literature, the researches on the education programs aimed at supporting cognitive skills shows that these programs also support the language skills of the children (Haywood, 2013; Imbrosciano, 1997; Konak, Berberoğlu, Arıkan, Tuncer and İş-Güzel, 2010). Similar to the findings of this study, the Cognitive Skills Support Program designed for children aged between 61-72 months by İnal-Kızıltepe, Yaşar and Uyanık (2017) supports the development of language skills of the children in the experimental group. However, in addition to cognitive skills, there are many other programs developed to support the language skills of children in early childhood (Aram, Fine and Ziv, 2013; Akoğlu, Duman \& Ergül, 2014; 
Beck \& McKeown, 2007; Krauss, Januszka \& Chae, 2010; Şimşek \& Erdogan, 2015; Towson, Gallagher \& Bingham, 2016).

In the study, the mean scores of Early Geometry Skill Test of the children in the experimental group and the control group were examined. This examination shows that the posttest mean scores of the children in both the experimental and the control groups are found to be higher than the pretest mean scores. This finding suggests that both the Cognitive Support Program and the preschool education program implemented by the Ministry of National Education support the development of children's geometry skills. In addition, comparison of the posttest mean scores of the experimental and the control groups shows that the mean scores of the Early Geometry Skills Test of the children in the experimental group were higher than the mean scores of the children in the control group. This can be interpreted as that the Cognitive Support Program increases the geometry skills of children more than the program implemented by the Ministry of National Education. Researches in the literature show that the computer aided education program developed by Kesicioğlu (2011) supports the preschool children to learn geometric shape concepts. In general, however, geometry skills are discussed under mathematical skills in the literature. For example, Meriwether (1997) prepared a mathematical arrangement of the food on the breakfast menu with the aim of providing mathematics education to children in a concrete way through their daily lives. The cheese in the menu was a cube, the apple and the orange were half circles, the biscuits were full circles, the milk and the fruit juice in the cup were in the form of cylinders and the children will draw the amount. Meriwether asked from the children to make their own menus showing how to form a menu, and observed that the children learned the geometric shapes and the amounts of shapes (quoted in Dinçer, 2008). As in this study, it is seen that geometry skills are handled together with math skills.

The effects of the Cognitive Support Program on children's mathematics skills have been tested. According to the results, the posttest mean scores of the children in the experimental group are found to be higher than the pretest mean scores in all subscales of the Early Numeracy Test. Similarly, the posttest mean scores of the children in the control group were higher than the pre-test scores in General Knowledge on Numbers and Calculation subscales of the Early Numeracy Test. However, their pretest mean scores in One to One Correspondence and Counting subscales are higher than the posttest mean scores. It is thought that the higher pretest mean scores in these subscales may be caused by the motivations of the students during the measurement. In addition, it was determined that there is no significant difference between the pre-test and the posttest mean scores in other subscales of the test, namely in Concepts Comparison, Classification, Seriation, Structured Counting and Resultative Counting subscales.
When the posttest means scores of the children in the experimental and control groups were examined, it was found that the mean scores of the experimental group in Concepts Comparison, One to One Correspondence, Counting, Structured Counting, Resultative Counting and Calculation of Early Numeracy Test are higher than the control group children. When the results on the development of the mathematical skills of the children in the experimental and the control groups are evaluated together, Cognitive Support Program is considered to be more effective in the development of mathematics skills of the children compared to the currently applied MEB Preschool education program. When the literature was examined, Young-Loveridge (2004) designed a training program based on games for early childhood and books on numbers, and it was found that this program causes a highly significant change on the number perceptions of children. Çelik and Kandır (2013) conducted the Great Math Education Program for Little Children, which was found to have a positive effect on children's early mathematics skills. In addition, there are some researches which considers the relationship between cognitive and mathematical skills as reversed. For example, a mathematics education program, which is developed by Kidd, Pasnak, Gadzichowski, Ferral-Like and Gallington (2008), based on number counting, collecting objects, comparing objects by quantity, sorting the numbers, was found to support one of the cognitive skills of children, namely reasoning, positively.

The last variable of the study is the effect of the Cognitive Support Program on children's readiness to primary school. It is found that the posttest mean scores of the children in the experimental group in Mathematics skills, Science skills, Sound studies and Drawing studies subscales of the Marmara Primary School Readiness Scale - Application Form are higher than the pretest mean scores. It is found that the mean scores of the students in the control group in Mathematics skills and Science skills subscales are higher than the pretest mean scores. Finally, the posttest mean scores of the children in the experimental group in Mathematical skills subscale of the Marmara Primary School Readiness Scale are found to be higher than the children in the control group. This result supports the results of the "Early Numeracy Test", which is another variable of the study, in favor of the experimental group. However, the difference between the posttest mean scores of the experimental and the control groups is not found to be significant in Science skills, Sound studies, Drawing studies and Labyrinths subscales of Marmara Primary School Readiness Scale - Application Form. This result demonstrates that Cognitive Support Program and the MEB Preschool Education Program, which is currently being implemented, similarly support primary school readiness levels. Preparatory studies to primary school are defined in Turkey 2003 preschool education program as the whole of the studies in which all the developmental areas 
for children are supported equally during the period of attending preschool education institutions, and it is emphasized that the whole of preschool education program is also preparatory program for primary education (Ministry of National Education, 2013). Therefore, there is no significant difference between the Cognitive Support Program and MEB preschool education program since both are designed and applied in a similar way.

In the literature, the cognitive and social support programs developed for early childhood are mostly directed towards socio-economically disadvantaged children (Bryant \& Maxwell, 1997; Campbell, Pungello, Miller-Johnson, Burchinal \& Ramey, 2001; Krajewski, Renner, Nieding \& Schneider, 2008; Vinnerljung \& Hjern, 2011). Research conducted by Campbell, Pungello, Miller-Johnson, Burchinal, and Ramey (2001) with African-Americans found that supportive training in early childhood had a long-term effect on children's cognitive and academic development. In addition, various programs, such as Abecedarian (Campbell et al. 2002), Perry Preschool (Heckman et al. 2010), and Chicago ChildParent Center (Reynolds et al. 2011), have also long-term benefits. However, the benefits of these programs are not generalizable since the scope of their targets is limited to the children with lower socio-economic status and certain cultural backgrounds. Therefore, it is considered that this program applied for children who have a normal development, who have a middle socio-economic family background and who are living in the city is important for their cognitive development.

It has been observed in the research that Cognitive Support Program has a positive effect on the language skills, geometry skills and math skills of preschool children but it is similar to that of preschool education program in terms of readiness to primary school. Skills that can be handled under the framework of cognitive development such as reasoning skills or voice-reading awareness are not discussed in the study. The effects of the developed program on these variables can be examined. In addition, this program can be improved in terms of readiness to primary school.

\section{REFERENCES}

[1] Akoğlu, G., Ergül, C., \& Duman, Y. (2014). Etkileşimli kitap okuma: korunmaya muhtaç çocukların alıcı ve ifade edici dil becerilerine etkileri. (Interactive reading: the effects on receptive and expressive language skills of children in need of protection.) İlköğretim Online, 13(2), 622 639. Retrieved from http://ilkogretim-online.org.tr/ind ex.php/io/article/view/2123

[2] Aram, D., Fine, Y. \& Ziv, M. (2013). Enhancing parentchild shared book reading interactions: Promoting references to the book's plot and socio-cognitive themes. Early Childhood Research Quarterly, 28(1), 111-122. Doi:

\subsection{6/j.ecresq.2012.03.005}

[3] Arthur, L.M. (2001). High quality early literacy programs. (Educating Children, Research) Leonie Australian Journal of Early Childhood, 26 (2); 41-53

[4] Avcı, N. (2003). Yaşama merhaba-gelişimde 0-3 Yaş (Hello Life - 0-3 years in development). Morpa Kültür Yay. Çocuk Gelişimi ve Eğitimi Dizisi, İstanbul.

[5] Beck I. L. \& McKeown M. G. (2007). "Increasing young low-income children's oral vocabulary repertoires through rich and focused instruction". The Elementary School Journal 107/3 (2007) 251-271.

[6] Berk, L. E. (2013). Child development (9th ed.). Boston, MA: Pearson.

[7] Boehm, A. E. (2001). Boehm preschool examine's manual. The Psychological Corporation, U.S.A: Hartcourt Assesment Company.

[8] Brewer, A.J. (1995). Early childhood education preschool through primary grades, A Simon \& Schuster Company Needham Heights, Mass. 02194

[9] Brooks, J. G., \& Brooks, M. G. (2001). In search for understanding the case for constructivist classrooms. New Jersey: Prentice-Hall.

[10] Bryant, D. M., \& Maxwell, K. (1997). The effectiveness of early intervention for disadvantaged children. In M. J. Guralnick (Ed.), The effectiveness of early intervention (pp. 23-46). Baltimore: Brookes.

[11] Burger, F. W., \& Shaughnessy, J. M. (1986). Characterizing the van Hiele levels of development in geometry. Journal for Research in Mathematics Education, 17(1), 31-48.

[12] Campbell, F. A., Pungello, E. P., Miller-Johnson, S., Burchinal, M., \& Ramey, C. T. (2001). The development of cognitive and academic abilities: growth curves from an early childhood educational experiment. Developmental psychology, 37(2), 231-242.

[13] Campbell, F. A., Ramey, C. T., Pungello, E., Sparling, J., \& Miller-Johnson, S. (2002). Early childhood education: Young adult outcomes from the Abecedarian Project. Applied developmental science, 6(1), 42-57.

[14] Çelik M. \& Kandır A. (2013). “61-72 Aylık çocukların matematik gelişimine 'küçük çocuklar için matematik' (Big Math for Little Kids) eğitim programının etkisi” (the effect of educational program "big math for little kids" on mathematical development of 61-72 Months Old Children). Kuramsal Eğitim Bilim Dergisi (Theoretical Education Scientific Journal). 6/4 (2013) 551-567. Doi: http://dx.doi.org/10.5578/keg.6712

[15] Charlesworth, R., \& D.J. Radeloff (1991). Experiences in math for young children. Second Edition. Delmar Publishers Inc. Albany, New York, USA.

[16] Christensen, L.B., Johnson, R.B., \& Turner, L.A. (2015). Research methods design and analysis. Cambridge: Pearson [Çeviri: Sever, M. (2015). Nitel ve karma yöntem araştırmaları. (Çev. Ed. A. Aypay) Araştırma yöntemleri desen ve analiz, Ankara: Anı Yayın.]

[17] Clark, E. (1983). Meaning and concept. Handbook of Child psychology, Vol 3: Cognitive Development. 
[18] Deveci, H. (2003). Sosyal bilgiler dersinde probleme dayal1 öğrenmenin öğrencilerin derse ilişkin tutumlarına, akademik başarılarına ve hatırlama düzeylerine etkisi. (The effect of problem based learning in social studies course on attitudes, academic achievements and levels of recall of students) Eskişehir: Anadolu University Press

[19] Dinçer, Ç. (2008). Okul öncesi eğitimde matematik. Uluslararası "Çocuk, Aile ve Okul Bağlamında Okul Öncesi Eğitim” Kongre Kitabı (Mathematics in preschool education. International "Preschool Education in the Context of Child, Family, and School" Conferernce Book, $55-60$

[20] Driscoll, A., \& Nagel, N.G. (2002). Early childhood education, birth-8: The world of children, families, and educators, My Lab School Edition, ISBN: 0-205- 46374-6, Publisher: Allyn \& Bacon

[21] Erdem, E., \& Demirel, Ö. (2002). Program geliștirmede yapılandırmacılık yaklaşımı. (Constructivist approach in program development) Hacettepe Üniversitesi Eğitim Fakültesi Dergisi (Hacettepe University Journal of Education), 23, 81-87.

[22] French, L.A., \& Nelson, K. (1985). Young children's knowledge of relationel termes: some ifs, or buts. New York: Springer-Verlag

[23] Gander, M. \& Gardiner, H. (2015). Çocuk ve ergen gelişimi (Child and adolescent development), Bekir Onur, trans. İmge Press, İstanbul.

[24] Güneysu, S. (2001). Neden erken çocukluk eğitimi? (Why early childhood education?) Çoluk Çocuk Dergisi (Kids and Children Journal). (2).

[25] Haywood, H.C. (2013). What is cognitive education? The view from 30,000 feet. Journal of Cognitive Education and Psychology, 12(1), 26-44. doi:10.1891/1945-8959.12.1.26. (Avaiable online at:http://www.researchgate.net/publicatio $\mathrm{n} / 265553229)$

[26] Heckman, J. J., Moon, S. H., Pinto, R., Savelyev, P. A., \& Yavitz, A. (2010). The rate of return to the HighScope Perry Preschool Program. Journal of public Economics, 94(1-2), 114-128.

[27] Imbrosciano, A. (1997). Philosophy and student academic performance. Critical and Creative Thinking, 5 (1), 35-41.

[28] İnal-Kızıltepe, G.; Yaşar, M. C.; Uyanık, Ö. (2017). Bilişsel becerileri destekleme programının 61-72 aylık çocukların yaratıcı düşünme, akademik ve dil becerilerine etkisi (The Effect of Cognitive Skills Supporting Program on Creative Thinking, Academic and Language Skills of 61-72 Months Old Children) Hacettepe Üniversitesi Eğitim Fakültesi Dergisi (H. U. Journal of Education) 32(3): 612-629

[29] Jackman, L.H. (2005). Early education curriculum: a child's connection to the world, Third Edition, Thomson Delmar Learning, NY.

[30] Katz, E., Blumler, J.G., \& Gurevitch, M. (1974). Uses and gratifications research. Public Opinion Quarterly, 37(4), 509-524. Retrieved 15, April, 2012, from: Sciences direct database.

[31] Katz, J., Ö., F., Demir, N., Uzlukaya, A., \& Uludağ, P. (1974), "A turkish peabody picture-vocabulary test",
Hacettepe Bulletin of Social Sciences and Humanities, Vol. 6(1-2), s. 129-142.

[32] Katz, L.G. (1999). Another look at what young children should be learning. Child Development, 7, 18-27.

[33] Kesicioğlu O. S. (2011). Doğrudan öğretim yöntemiyle hazırlanan eğitim programının ve bu yönteme göre hazırlanan bilgisayar destekli eğitim programının okul öncesi çocuklarının geometrik şekil kavramlarını ögrenmelerine etkisinin incelenmesi. (Examination of the effect of the curriculum prepared by direct instruction method and computer aided education program prepared according to this method on the learning of conceptions of geometric shape of preschool children.) Gazi University Institute of Education Sciences, Unpublished Doctoral Dissertation

[34] Kidd J. K., Pasnak R., Gadzichowski M., Ferral-Like M. \& Gallington D. (2008). Enhancing early numeracy by promoting the abstract thought involved in the oddity princible, seriation and conversation. Journal of Advanced Academics 19/2 (2008) 164-200

[35] Koçak, N. (2001). Erken çocukluk döneminde eğitim ve Türkiye'de erken çocukluk eğitiminin durumu. (Early childhood education and the status of early childhood education in Turkey) Milli Eğitim Dergisi (Journal of National Education), 151.

[36] Konak, Ö.A., Berberoğlu, G., Arıkan, Tuncer, Ç.Ö., \& İş-Güzel, Ç. (2010). Okula hazırbulunuşluk kapsamında bilişsel ve dil becerileri. (Cognitive and language skills within the context of school readiness). Cito Eğitim: Kuram ve Uygulama (Cito Education: Theory and Practice), 8, 9-20.

[37] Krajewski, K., Renner, A., Nieding, G., \& Schneider, W. (2008). Frühe Förderung von mathematischen Kompetenzen [Early training of quantity-number competencies in preschool]. Zeitschrift für Erziehungswissenschaft, Sonderheft, 11, 91-103.

[38] Krauss, L., Januszka, C. M., \& Chae, C. (2010). Development of dialogic reading inventory of parentchild book reading. Journal of Research in Childhood Education, 24, 266-277.

[39] Küçükkaragöz, H. (2004). Bilișsel gelişim ve dil gelișimi. Gelişim ve öğrenme psikolojisi (Cognitive development and language development. Development and learning psychology) (Binnur Yeşilyaprak, eds.). Ankara: Pegem A Press.

[40] Küçükturan, G. (2003). Okul öncesi fen öğretiminde bir teknik analoji. (A technical analogy in teaching science in preschool) Milli Eğitim Dergisi (Journal of National Education).

[41] MEB (Ministry of National Education). (2013). Okul öncesi eğitimi programı (Preschool education program). ankara: ministry of national education training council.

[42] Oakley, L. (2004). Cognitive development, London: Routledge

[43] Oktay, A. (2004). Yaşamın sihirli yılları: Okul öncesi dönem. (The magical years of life: Preschool period) İstanbul: Epsilon Press. 
[44] Oktay, A. (2007). Okul öncesi eğitimden ilköğretime geçiş projesi. Türkiye Özel Okullar Birliği Derneği, Okul Öncesi Eğitimi, Öğretmen Eğitimi. (Project of transition from preschool to primary education. Turkey Association of Private Schools, Preschool Education, Teacher Education.) 01 Şubat 2007. Antalya. İstanbul: Neta.

[45] Önkol, L. (2012). Erken Sayı Testi'nin uyarlanması ve erken sayı gelişim programının 6 yaş çocukların sayı gelişimlerine etkisinin incelenmesi, (Adaptation of early numeracy test and investigation of the effect of early numeracy development program on numeracy development of 6 years old children) Marmara University Institute of Education Sciences, Unpublished Doctoral Dissertation.

[46] Özbek, R. (2005). Öğretmen algılarına göre eğitim fakültesi öğretim programının, ilköğretim öğretim ortamlarının ve öğretmenlerin "yapılandırmacı öğretim” anlayışına yönelik düşuncelerinin değerlendirilmesi. (The evaluation of the curriculum of the faculty of education, primary education environments and teachers' ideas on "constructivist teaching" according to the perceptions of the teachers.) XIV. National Education Sciences Conference, Pamukkale University Faculty of Education, September 28-30, DENIZLİ, 409-416.

[47] Pallant, J. (2001). SPSS survival manual: A step by step to data analysis using SPSS. Australia: Allen \& Unwin.

[48] Peker, R. (2001). Gelişim psikolojisine genel bakış. (Overview of developmental psychology.) Altıntaş, E., eds., Gelişim ve Öğrenme (Development and Learning), Akınoğlu Press, Bursa.

[49] Reynolds, A. J., Temple, J. A., White, B. A., Ou, S. R., \& Robertson, D. L. (2011). Age 26 cost-benefit analysis of the child-parent center early education program. Child development, 82(1), 379-404.

[50] Senemoğlu, N. (2005). Gelişim öğrenme ve öğretim. (Development, learning and teaching) Ankara: Gazi Press.

[51] Sevinç, M. (2005). Gelişim ve eğitimde yeni yaklaşımlar. (New perspectives on development and education) İstanbul: Morpa Kültür Press.

[52] Sezer, T. (2015). "Erken geometri beceri testi'nin geliştirilmesi ve çocukların geometri becerilerinin incelenmesi", (Development of early geometry skills test and investigation of children's geometry skills) Marmara University Institute of Education Sciences, Unpublished Doctoral Dissertation.

[53] Şimsek, Z. C., \& Erdogan, N. I. (2015). Effects of the dialogic and traditional reading techniques on children's language development. Procedia-Social and Behavioral Sciences, 197, 754-758. Access address:http://www.scienc edirect.com/science/article/pii/S1877042815041737

[54] Towson, J. A., Gallagher, P. A., \& Bingham, G. E. (2016). Dialogic reading: language and preliteracy outcomes for young children with disabilities. Journal of Early Intervention, 38(4), 230-246. Access address: http://scholarworks.gsu.edu/epse_diss/106

[55] Unutkan, Ö.P. (2003). Marmara ilköğretime hazır oluş ölçeğinin geliștirilmesi ve standardizasyonu. (Development and standardization of Marmara primary school readiness scale) Marmara University Institute of Education Sciences, Unpublished Doctoral Dissertation.
[56] Ünver, G., Ulusoy, A., Güngör, A., Köksal Akyol, A. and Koç, G. (2003). Gelişim ve öğrenme, (Development and learning) Anı Press, Ankara.

[57] Van Luit, J. E. H., Van de Rijt, B. A. M., \& Pennings, A. H. (1994). Utrechtse getalbegrip toets [early numeracy test]. Doetinchem, The Netherlands: Graviant.

[58] Vinnerljung, B., \& Hjern, A. (2011). Cognitive, educational and self-support outcomes of long-term foster care versus adoption. A Swedish national cohort study. Children and Youth Services Review, 33(10), 1902-1910.

[59] Vygotsky, L. S. (1994). The development of academic concepts in school aged children. In R. Van der Veer \& J. Valsiner (Eds.), The Vygotsky reader (pp. 335 - 370). Oxford, England: Blackwell

[60] Yalaz, K., \& Anlar, B. \& Bayoğlu, B. U., (2010). Denver II gelişimsel tarama testi (Denver II developmental survey), Ankara: Developmental Neurology of Children Association

[61] Yavuzer, H. (2016). Çocuğunuzun ilk 6 yıl1. (First 6 year of your child) İstanbul: Remzi Press.

[62] Yavuzer, H. (2016a). Çocuk psikolojisi. (Psychology of children) 34th Edition: Remzi Press.

[63] Yıldız, R., \& Perihanoğlu, P. (2004). Okul öncesi eğitim kurumlarının eğitim hedeflerini gerçekleştirme düzeyi. (Level of realizing educational objectives of pre-school education institutions.) 12th Education Sciences Conference. Gazi University Institute of Education Sciences. 15-18 October 2003. Antalya.

[64] Young-Loveridge J. M. (2004). "Effects on early numeracy of a program using number books and games". Early Childhood Research Quarterly 19/1 (2004) 82-98. Doi: 10.1016/j.2004.01.001 